\title{
Renewable Butanol Production via Catalytic Routes
}

\author{
Heeyoung Choi ${ }^{1}$, Jeehoon Han ${ }^{2, *}$ (D) and Jechan Lee ${ }^{1,3, *(\mathbb{D})}$ \\ 1 Department of Environmental and Safety Engineering, Ajou University, Suwon 16499, Korea; \\ chk6788@ajou.ac.kr \\ 2 School of Semiconductor and Chemical Engineering \& School of Chemical Engineering, Jeonbuk National \\ University, Jeonju 54896, Korea \\ 3 Department of Energy Systems Research, Ajou University, Suwon 16499, Korea \\ * Correspondence: jhhan@jbnu.ac.kr (J.H.); jlee83@ajou.ac.kr (J.L.)
}

Citation: Choi, H.; Han, J.; Lee, J. Renewable Butanol Production via Catalytic Routes. Int. J. Environ. Res Public Health 2021, 18, 11749. https:// doi.org/10.3390/ijerph182211749

Academic Editors: Haris Nalakath Abubackar, Tugba Keskin,

Luciana Peixoto, Azize Ayol and Chunping Yang

Received: 13 October 2021

Accepted: 8 November 2021

Published: 9 November 2021

Publisher's Note: MDPI stays neutral with regard to jurisdictional claims in published maps and institutional affiliations.

Copyright: (c) 2021 by the authors. Licensee MDPI, Basel, Switzerland. This article is an open access article distributed under the terms and conditions of the Creative Commons Attribution (CC BY) license (https:// creativecommons.org/licenses/by/ $4.0 /)$

\begin{abstract}
Fluctuating crude oil price and global environmental problems such as global warming and climate change lead to growing demand for the production of renewable chemicals as petrochemical substitutes. Butanol is a nonpolar alcohol that is used in a large variety of consumer products and as an important industrial intermediate. Thus, the production of butanol from renewable resources (e.g., biomass and organic waste) has gained a great deal of attention from researchers. Although typical renewable butanol is produced via a fermentative route (i.e., acetone-butanol-ethanol (ABE) fermentation of biomass-derived sugars), the fermentative butanol production has disadvantages such as a low yield of butanol and the formation of byproducts, such as acetone and ethanol. To avoid the drawbacks, the production of renewable butanol via non-fermentative catalytic routes has been recently proposed. This review is aimed at providing an overview on three different emerging and promising catalytic routes from biomass/organic waste-derived chemicals to butanol. The first route involves the conversion of ethanol into butanol over metal and oxide catalysts. Volatile fatty acid can be a raw chemical for the production of butanol using porous materials and metal catalysts. In addition, biomass-derived syngas can be transformed to butanol on non-noble metal catalysts promoted by alkali metals. The prospect of catalytic renewable butanol production is also discussed.
\end{abstract}

Keywords: biomass; butanol; catalysis; organic waste; renewable chemical; sustainable chemistry

\section{Introduction}

The employment of fossil hydrocarbons has fostered population growth and prosperity, which has made our society heavily depend on fossil fuels and petroleum-derived chemicals. Recently, the demand for renewable fuels and chemicals has been increasing, associated with recent emphasis on less carbon-intensive options driven by environmental, social, and governance-minded investing strategies. The market size of renewable biobased chemicals was forecast to be 106 billion USD with a compound annual growth rate (CAGR) of $10.6 \%$ from 2020 to 2025 [1].

Butanol, a four-carbon alcohol, is a commodity organic chemical that has a wide range of applications in manufacturing (polymers, synthetic rubber, brake fluids, lubricants, etc.), pharmaceutical, and cosmetics industries. It has been employed not only as an industrial solvent but also as an intermediate to produce vital chemicals such as acetates, acrylate esters, amines, amino resins, butyl acrylate, glycol ether, and methacrylate [2]. The global butanol market was valued at approximately 7 billion USD in 2020, expected to reach approximately 9 billion USD by 2026 with a CAGR of $3.7 \%$ from 2021 to 2026 [3]. Current commercial production of butanol is based on petroleum-derived chemicals. However, the petrochemical production of butanol is susceptible to the price of crude oil that fluctuates considerably. In addition to fluctuating crude oil price, the depletion of fossil fuel resources and the serious global environmental issue, climate change caused by global warming, have spurred the use of renewable sources (biomass, organic waste, etc.) as the feedstock for the production of commodity chemicals such as butanol. 
The use of biofuels is crucial to reduce the use of fossil fuels. There is stimulating demand for biofuels, estimated to reach approximately 51 billion gallons per year by 2022 [4]. Although ethanol has been the most used biofuel, butanol (mostly n-butanol) is considered a better source of alternative fuel than ethanol because of its about 1.5 times higher energy density than ethanol [5]. Butanol is also less volatile, less corrosive, and less hygroscopic than ethanol, not only resulting in fewer ignition problems in engines but also allowing a safer engine operation without any modification [6-8] In addition, the combustion of butanol leads to a lower $\mathrm{CO}_{2}$ emission than that of ethanol and even gasoline [9], with no emission of nitrogen oxides and sulfur [10]. In this regard, the demand for the renewable butanol production is stimulating.

Biological production of butanol is considered a carbon-neutral pathway from biomass to butanol (i.e., biobutanol). Acetone-butanol-ethanol (ABE) fermentation, a process that employs bacterial fermentation using Clostridium spp. to produce acetone, $\mathrm{n}$-butanol, and ethanol from carbohydrates such as starch and glucose, is the most widely studied method to convert biomass into butanol [11]. Nevertheless, ABE fermentation for biobutanol production still confronts significant challenges. The process results in byproducts, such as acetone, ethanol, 2-propanol, milk acid, and propanoic acid, which cause not only a decrease in the n-butanol yield but also an increase downstream processing cost for the purification of n-butanol [12]. In addition, the native microorganisms used for ABE fermentation (Clostridium spp.) suffer from solvent toxicity, complicated nutrient requirements, slow growth, and complex life cycle (i.e., the production of spores in Clostridium) [13,14]. It is also challenging to modify native producer strains using different genetic and synthetic biological methods [15]. High feedstock cost and high water usage are other challenges for ABE fermentation that hinder large scale production of butanol via the biological route [14]. The drawbacks of the fermentative biobutanol production highly necessitates the production of butanol from renewable resources (e.g., biomass) via nonfermentation routes.

Catalytic production of butanol from biomass-derived compounds has recently attracted great attention as an alternate route to synthesize renewable butanol. The primary advantage of catalytic routes is that they involve simple steps to achieve relatively high yields of butanol compared with fermentative route [16]. Given recent scientific research output, this review provides an up-to-date summary of knowledge of the catalytic conversion of biomass-derived compounds into butanol. We discuss catalysts investigated to transform different biomass-derived chemicals into butanol outlining various catalytic routes from the biomass compounds to butanol. Present challenges and perspectives of the catalytic production of renewable butanol are also discussed.

\section{Butanol Production from Ethanol}

As is well known, a large volume of ethanol made from renewable carbon-neutral resources (i.e., biomass), called bioethanol, is being employed not only as a biofuel additive for gasoline $[17,18]$ but also as a feedstock of various chemicals [19-22]. Approximately 98.4 billion liters of bioethanol was produced in 2018 [23]; however, its water solubility, corrosivity, and the differences in fuel properties between bioethanol and conventional transportation fuels (e.g., gasoline) make it unsuitable to employ ethanol fuel in modern internal combustion engines [24]. Hence, the use of ethanol as the feedstock for the production of butanol has great potential. The process that converts ethanol to n-butanol is industrialized, which increases the carbon number by coupling two ethanol molecules. The Guerbet reaction is an aldol-condensation-type reaction of coupling alcohols, involving oxidation of alcohol to aldehyde, aldol condensation of the aldehyde to allyl aldehyde, and hydrogenation of the allyl aldehyde to its corresponding alcohol [25]. For the reaction from ethanol to n-butanol, dehydrogenation of ethanol occurs first to make acetaldehyde [26]. Aldol condensation of acetaldehyde to crotonaldehyde then takes place, followed by hydrogenation to form n-butanol [27]. The conversion of ethanol to n-butanol is described in Figure 1. 


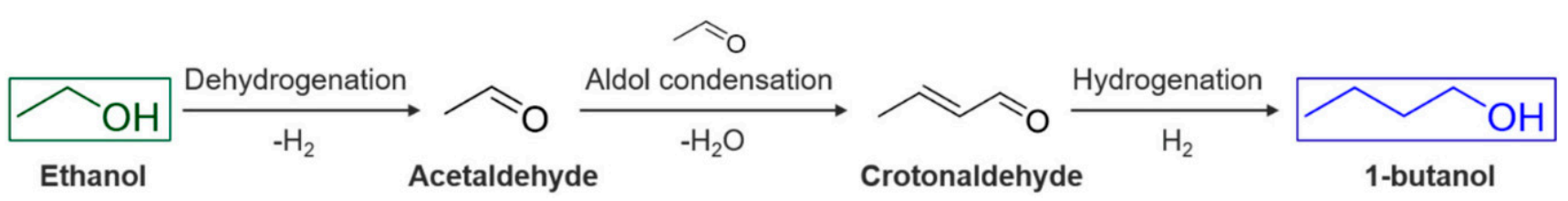

Figure 1. Representative reaction pathway for the conversion of ethanol to n-butanol via aldol condensation. Reprinted from Xi et al. [28] and licensed under CC BY 4.0.

Various homogeneous and heterogeneous catalysts are available for the Guerbet reaction. For the homogeneously-catalyzed Guerbet reaction (taking place at $150-160{ }^{\circ} \mathrm{C}$ ), $\mathrm{Ru}$ - or Mn-based homogeneous catalysts have been reported [29-35]. Despite high ethanol selectivity $(>90 \%)$, the homogeneous Guerbet process leads to undesirable byproducts such as $\mathrm{C}_{6+}$ alcohols and sodium acetate [36]. In addition, the separation of catalyst from the reaction product (i.e., butanol) is another issue of the homogeneous reaction $[37,38]$.

To avoid such problems, various heterogeneous catalyst systems that allow direct conversion of ethanol to n-butanol have been suggested [39-44]. Solid acid-base catalysts have been tested. For instance, a commercially available hydroxyapatite catalyst led to about $50 \%$ selectivity toward butanol at $350-440{ }^{\circ} \mathrm{C}$ with an indication of the formation of byproducts such as $\mathrm{H}_{2}$ and acetaldehyde [45]. Kozlowski and Davis experimentally proved that an increase in the density of base sites on a $\mathrm{ZrO}_{2}$ catalyst by an addition of 1 wt.\% Na enhances the selectivity toward n-butanol because the dehydration of ethanol is significantly inhibited [46].

Ogo et al. synthesized four catalysts (Ca-P, Ca-V, Sr-P, and Sr-V) used for ethanol conversion to n-butanol [47]. The ethanol conversion reaction was conducted at $300{ }^{\circ} \mathrm{C}$ with a space velocity of $130 \mathrm{~h} \mathrm{~g}_{\text {cat. }}$. ol $_{\text {ethanol }}{ }^{-1}$. The Sr-P catalyst provided the highest selectivity toward n-butanol amongst the catalysts tested. This was because the Sr-P catalyst not only provided a high selectivity toward crotonaldehyde resulting from aldol condensation of acetaldehyde (an intermediate of n-butanol; Figure 1) but also inhibited the coke formation occurring in the hydrogen transfer reaction of 2-buten-1-ol into n-butanol. As the molar ratio of $\mathrm{Sr} / \mathrm{P}$ became higher, the selectivity toward n-butanol was enhanced [48]. The density of strong acid and base sites increased as the molar Sr/P ratio increased, and the base site density was much higher than the acid site density. Aldol condensation was expedited by base catalysis; thus, the Sr-P catalyst having a higher base site density resulted in a higher catalytic activity for the production of 1-butanol from ethanol.

Catalysts consisting of $\mathrm{Mg}$ and $\mathrm{Al}$ have been investigated as an effective catalytic system for the selective conversion of ethanol to n-butanol. For example, modified $\mathrm{MgO}$ catalyst at $450{ }^{\circ} \mathrm{C}$ and $1 \mathrm{~atm}$ could transform ethanol into n-butanol [49]. It was proposed that the mechanism of the ethanol conversion over the $\mathrm{MgO}$ catalyst is similar to the case of basic zeolite: the basic metal oxide activates the $\mathrm{C}-\mathrm{H}$ bond in $\beta$-position of ethanol followed by its condensation with another ethanol molecule via dehydration, resulting in the formation of n-butanol [50]. Other acid-base catalysts, e.g., $\mathrm{Mg}-\mathrm{Al}$ mixed oxides, were investigated in a one-pot conversion of ethanol to n-butanol [51]. It was shown that a $\mathrm{Mg}-\mathrm{Al}$ mixed oxide with a $\mathrm{Mg} / \mathrm{Al}$ ratio of 3 led to $~ 38 \%$ selectivity toward n-butanol at an ethanol conversion of $\sim 35 \%$ at $350{ }^{\circ} \mathrm{C}$ under $1 \mathrm{~atm}$. The catalyst characterization results proved that adjacent acid and medium basic sites ( $\mathrm{Al}$ inserted in $\mathrm{MgO}$ lattice or $\mathrm{Mg}$ inserted in $\mathrm{Al}_{2} \mathrm{O}_{3}$ lattice) promote the formation of butanol, because the presence of both sites is needed to form the reaction intermediate species. The $\mathrm{Mg}-\mathrm{Al}$ oxide with a $\mathrm{Mg} / \mathrm{Al}$ ratio of 3:1 led to a faster formation of intermediates to n-butanol (i.e., acetaldehyde and crotonaldehyde) than the $\mathrm{Mg}-\mathrm{Al}$ oxide with a $\mathrm{Mg} / \mathrm{Al}$ ratio of 1:1 [52]. This was due to fewer surface carboxylate functionalities on the $\mathrm{Mg}-\mathrm{Al}$ oxide $(\mathrm{Mg} / \mathrm{Al}=3 / 1)$ than the $\mathrm{Mg}-\mathrm{Al}$ oxide $(\mathrm{Mg} / \mathrm{Al}=1 / 1)$, given that the carboxylate functionalities compete with the catalytic active sites. León et al. also showed that higher concentration and strength of basic sites on $\mathrm{Mg}-\mathrm{Al}$ mixed oxide catalyst resulted in higher selectivity toward $\mathrm{C}_{4}$ fractions for the ethanol conversion, while the presence of acid sites on the $\mathrm{Mg}-\mathrm{Al}$ mixed oxide catalyst decreased the activity for condensation reaction by promoting ethanol dehydration [53]. 
The water might be continuously removed from the reaction mixture in order to further enhance the selectivity toward n-butanol [54].

Other than the aforementioned solid acid-base catalysts, the butanol production from ethanol over metal catalysts has been reported. Riittonen et al. screened a variety of supported metal catalysts $(\mathrm{Pt}, \mathrm{Ru}, \mathrm{Rh}, \mathrm{Ag}, \mathrm{Au}$, and $\mathrm{Ni}$ ) to find active catalysts for the direct conversion of ethanol to n-butanol [55]. The selectivity towards n-butanol followed an order of $\mathrm{Ni}>\mathrm{Pt}>\mathrm{Rh} \sim \mathrm{Au}>\mathrm{Ru}>>\mathrm{Ag}$. It was found that an $\mathrm{Al}_{2} \mathrm{O}_{3}$-supported $\mathrm{Ni}$ catalysts with a Ni loading of $20.7 \%$ was the most selective catalyst for the n-butanol production via dimerization of ethanol $(80 \%$ selectivity at $25 \%$ ethanol conversion at $250{ }^{\circ} \mathrm{C}$ ). A process that continuously converts ethanol to n-butanol using $\mathrm{Ni} / \gamma-\mathrm{Al}_{2} \mathrm{O}_{3}$ catalyst was developed by Ghaziaskar and $\mathrm{Xu}$ [56]. The reaction was carried out in a continuous-flow packed-bed reactor at a range of temperature between $135^{\circ} \mathrm{C}$ and $300{ }^{\circ} \mathrm{C}$ at a weight hourly space velocity (WHSV) between $6.4 \mathrm{~h}^{-1}$ and $15.6 \mathrm{~h}^{-1}$. The highest selectivity toward n-butanol (62\% at $35 \%$ ethanol conversion) was achieved with an $8 \%$ $\mathrm{Ni} / \gamma-\mathrm{Al}_{2} \mathrm{O}_{3}$ catalyst (stable for 18 -h time-on-stream) at $250{ }^{\circ} \mathrm{C}$ under $17.6 \mathrm{MPa}$. Dowson et al. used Ru-based homogeneous catalysts to transform ethanol to n-butanol [57]. A $94 \%$ n-butanol selectivity at $>20 \%$ ethanol conversion was obtained. It was suggested that the homogeneous catalytic system tamed uncontrolled base-catalyzed aldol condensation of acetaldehyde. Figure 2 shows a schematic of a mechanism of ethanol conversion to n-butanol over alumina-supported metal catalysts [58]. It consists of adsorption of two ethanol molecules on the spinel surface (Figure 2A), oxidation of ethanol to acetaldehyde and aldol condensation between these compounds with the accommodation of hydrogen on metal oxide (Figure 2B), hydrogenation of crotonaldehyde to n-butanol (Figure 2C), and desorption of $n$-butanol from the catalyst surface (Figure 2D).

The aforementioned studies into the ethanol conversion to butanol emphasized evaluating bulk catalytic materials. The studies to use nanosized catalysts for the ethanol-tobutanol reaction are very limited. The employment of nanocatalysts may enhance the conversion of ethanol and the selectivity toward butanol, considering that they are shown to be more active, selective, and stable than bulk-structured catalysts for various ethanol conversion reactions [59-61]. For example, $\mathrm{Ce}-\mathrm{La}$ catalysts with a range of particle size between $1 \mathrm{~nm}$ and $10 \mathrm{~nm}$ required a lower temperature to obtain $100 \%$ ethanol conversion and had a greater stability (stable for $15 \mathrm{~h}$ time-on-stream without deactivation) than bulk catalytic materials [62]. Au nanoparticles (3-5 nm) dispersed on $\mathrm{SiO}_{2}$ were an active stable catalyst to oxidize ethanol to acetaldehyde, acetic acid, and acetyl acetate (37-58\% yield) at $210^{\circ} \mathrm{C}$ [63]. A nanosized HZSM-5 zeolite $(\sim 30 \mathrm{~nm})$ showed higher activity and selectivity toward gasoline-range hydrocarbons than a bulk HZSM-5 zeolite [64]. The nano-HZSM-5 catalyst had $74 \%$ selectivity with a research octane number (RON) of 91 at $450{ }^{\circ} \mathrm{C}$, while the bulk HZSM- 5 catalyst had 59\% selectivity with a RON of 87 .

In Table 1, a wide range of catalysts and relevant reaction conditions for the conversion of ethanol to n-butanol are summarized, based on the results reported in earlier literature available. 
<smiles>CCCO</smiles>
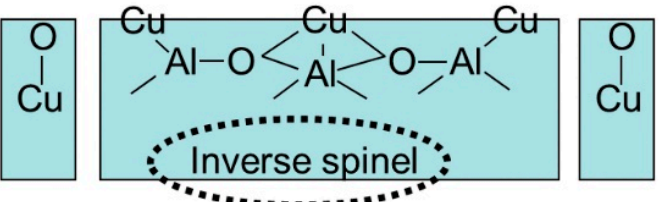

A. Adsorption of two ethanol molecules on the spinel surface

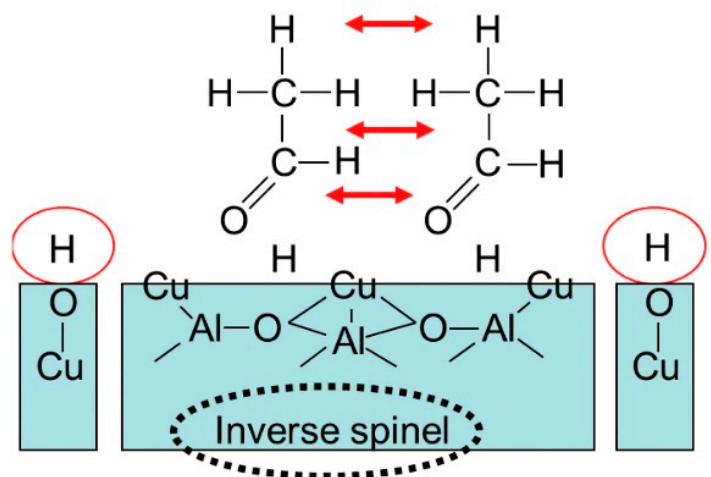

B. Oxidation of ethanol to acetaldehyde and aldol condensation between them. Accommodation of hydrogen on metal oxides.

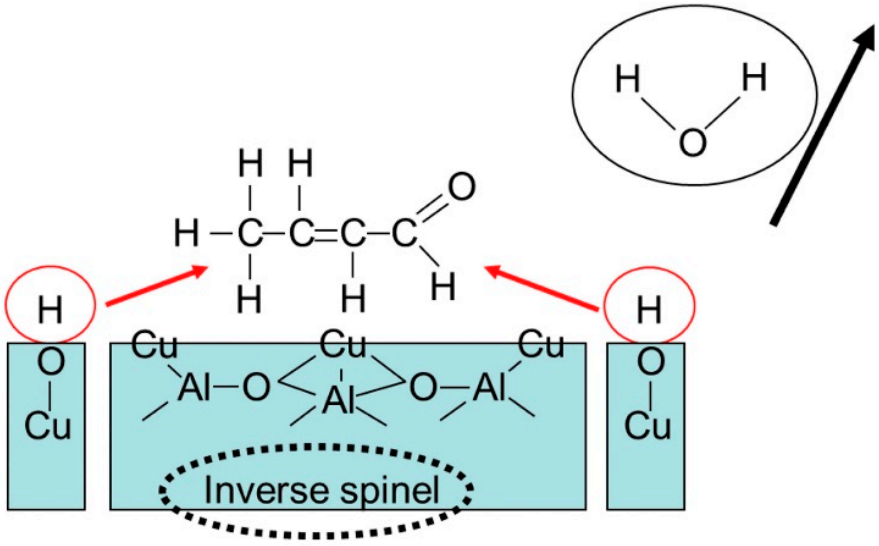

C. Hydrogenation of formed crotonaldehyde intermediate to 1-butanol.<smiles>CCCC</smiles><smiles>CCCCO</smiles>
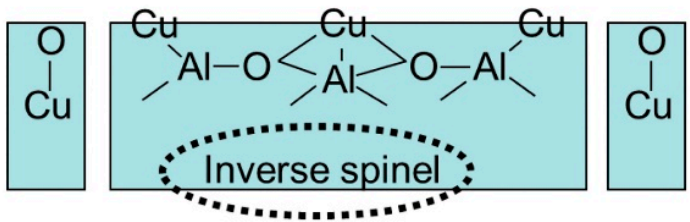

D. Desorption of 1-butanol from the catalyst surface.

Figure 2. Proposed ethanol conversion mechanism for the production of n-butanol on alumina-supported metal catalysts at $240{ }^{\circ} \mathrm{C}$ under $7 \mathrm{MPa}$. Reprinted from Riittonen et al. [58], Copyright (2014), with permission from Elsevier.

Table 1. Catalysts used for the conversion of ethanol to n-butanol. All the results are obtained from earlier literature.

\begin{tabular}{|c|c|c|c|c|c|c|}
\hline Catalyst & Reactor Type & Ethanol Phase & Reaction Conditions & $\begin{array}{c}\text { Ethanol } \\
\text { Conversion } \\
(\%)\end{array}$ & $\begin{array}{l}\text { Butanol } \\
\text { Selectivity } \\
(\%)\end{array}$ & Ref. \\
\hline $\begin{array}{l}\text { Hydroxyapatite }(\mathrm{Ca} / \mathrm{P} \\
\text { molar ratio of } 1.64)\end{array}$ & $\begin{array}{l}\text { Fixed-bed } \\
\text { reactor }\end{array}$ & Gas phase & $\begin{array}{l}300{ }^{\circ} \mathrm{C} ; 16.4 \text { vol. } \% \\
\text { ethanol in helium; } \\
\text { contact time of } 1.78 \mathrm{~s}\end{array}$ & 14.7 & 76.3 & [65] \\
\hline $\begin{array}{c}\mathrm{Mg}-\mathrm{Al} \text { hydrotalcite } \\
(\mathrm{Mg} / \mathrm{Al} \text { molar ratio } \\
\text { of } 3)\end{array}$ & $\begin{array}{l}\text { Packed-bed } \\
\text { reactor }\end{array}$ & Vapor phase & $\begin{array}{c}400{ }^{\circ} \mathrm{C} ; 5.5 \text { vol. } \% \text { ethanol } \\
\text { in helium }\left(30 \mathrm{~mL} \mathrm{~min}^{-1}\right) ; \\
\text { weight hourly space } \\
\text { velocity }(\mathrm{WHSV}) \text { of } \\
0.215 \mathrm{~h}^{-1}\end{array}$ & 25 & 16.1 & [53] \\
\hline $\begin{array}{l}\mathrm{Mg}-\mathrm{Al} \text { mixed oxide } \\
(\mathrm{Mg} / \mathrm{Al} \text { molar ratio } \\
\text { of } 3)\end{array}$ & $\begin{array}{l}\text { Fixed-bed } \\
\text { reactor }\end{array}$ & Vapor phase & $\begin{array}{c}350^{\circ} \mathrm{C} ; 12 \text { vol.\% ethanol } \\
\text { in } \mathrm{N}_{2}\left(40 \mathrm{~mL} \mathrm{~min}{ }^{-1}\right) ; \\
\text { 8-h reaction }\end{array}$ & $\sim 35$ & $\sim 38$ & [51] \\
\hline
\end{tabular}


Table 1. Cont.

\begin{tabular}{|c|c|c|c|c|c|c|}
\hline Catalyst & Reactor Type & Ethanol Phase & Reaction Conditions & $\begin{array}{c}\text { Ethanol } \\
\text { Conversion } \\
(\%)\end{array}$ & $\begin{array}{c}\text { Butanol } \\
\text { Selectivity } \\
(\%)\end{array}$ & Ref. \\
\hline $\begin{array}{l}\mathrm{Ni} / \mathrm{Al}_{2} \mathrm{O}_{3}(\mathrm{Ni} \text { loading } \\
\text { of } 20.7 \%)\end{array}$ & Batch reactor & Liquid phase & $\begin{array}{c}250^{\circ} \mathrm{C} \text {; catalyst/ethanol } \\
\text { ratio of } 3.3 / 100(w / v)\end{array}$ & 25 & 80 & [55] \\
\hline $\mathrm{Cu} / \mathrm{Al}_{2} \mathrm{O}_{3}, \mathrm{Ni} / \mathrm{Al}_{2} \mathrm{O}_{3}$ & $\begin{array}{l}\text { Fixed-bed } \\
\text { reactor }\end{array}$ & Liquid phase & $\begin{array}{c}240{ }^{\circ} \mathrm{C} ; 7 \mathrm{MPa} \text { (argon); } \\
\text { liquid hourly space } \\
\text { velocity (LHSV) of } \\
4.3 \mathrm{~L} \mathrm{~h}^{-1} \text {; ethanol } \\
\text { specific velocity of } \\
8.3 \times 10^{-6} \mathrm{~m} / \mathrm{s}\end{array}$ & $20-28$ & $60-65$ & [58] \\
\hline $\begin{array}{c}\mathrm{Ru}- \\
\text { bis(diphenylphosphanyl) } \\
\text { methane }\end{array}$ & Batch reactor & Liquid phase & $\begin{array}{c}150^{\circ} \mathrm{C} ; \mathrm{Ru} \text { of } 0.1 \text { mol. } \% \\
\mathrm{Ru} / \text { ligand molar ratio of } \\
1 ; 4 \mathrm{~h}\end{array}$ & $>20$ & 94 & [57] \\
\hline $\begin{array}{l}\text { Hydroxyapatite } \\
\text { (commercial) }\end{array}$ & $\begin{array}{l}\text { Fixed-bed } \\
\text { reactor }\end{array}$ & Vapor phase & $\begin{array}{l}438^{\circ} \mathrm{C} ; 15.2 \% \text { ethanol in } \\
\text { argon; WHSV of } 14 \mathrm{~h}^{-1}\end{array}$ & - & Yield: $15.5 \%$ & [45] \\
\hline $\mathrm{Sr}_{10}\left(\mathrm{PO}_{4}\right)_{6}(\mathrm{OH})_{2}$ & $\begin{array}{l}\text { Fixed-bed } \\
\text { reactor }\end{array}$ & Liquid phase & $\begin{array}{l}300^{\circ} \mathrm{C} ; 16.1 \text { mol. } \% \text { in } \\
\text { argon; space velocity of } \\
130 \mathrm{~h}_{\text {gcat. }} \text { mol }_{\text {ethanol }}-1 ; \\
\text { 3-h time-on-stream }\end{array}$ & 20 & $\sim 79$ & [47] \\
\hline $\mathrm{MgO}$ & $\begin{array}{l}\text { Fixed-bed } \\
\text { reactor }\end{array}$ & Liquid phase & $\begin{array}{c}450{ }^{\circ} \mathrm{C} ; 1 \mathrm{~atm} ; \mathrm{N}_{2} \text { flow of } \\
10 \mathrm{~mL} \mathrm{~min} \\
\end{array}$ & 56.1 & 32.8 & [49] \\
\hline $\begin{array}{l}\mathrm{Cu}-\mathrm{Mg}-\mathrm{Al} \\
\text { mixed oxide }\end{array}$ & Batch reactor & Liquid phase & $\begin{array}{l}200^{\circ} \mathrm{C} \text {; ethanol/catalyst } \\
\text { ratio of } 79 ; 100 \text {-h reaction }\end{array}$ & $\sim 11$ & $\sim 70$ & [54] \\
\hline $\begin{array}{l}\mathrm{Pd}-\mathrm{Mg}-\mathrm{Al} \\
\text { mixed oxide }\end{array}$ & Batch reactor & Liquid phase & $\begin{array}{c}260^{\circ} \mathrm{C} \text {; ethanol/catalyst } \\
\text { ratio of } 79 ; \mathrm{LHSV} \text { of } \\
15 \mathrm{~mL} \mathrm{~g}^{-1} \mathrm{~h}^{-1} \\
5 \text {-h reaction }\end{array}$ & 17.5 & 78 & [66] \\
\hline $\begin{array}{c}\mathrm{Ni} / \mathrm{ZrO}_{2} \\
\text { (Ni loading of } 1 \text { wt.\%) }\end{array}$ & $\begin{array}{l}\text { Fixed-bed } \\
\text { reactor }\end{array}$ & Vapor phase & $\begin{array}{c}400{ }^{\circ} \mathrm{C} ; 6.8 \mathrm{~mol} \% \\
\text { ethanol in } \mathrm{N}_{2} ; \\
0.52 \mu \mathrm{mol}_{\text {ethanol }} \mathrm{m}^{-2} \mathrm{~s}^{-1}\end{array}$ & 7.7 & 12 & [46] \\
\hline $\begin{array}{c}\mathrm{Ni} / \mathrm{Al}_{2} \mathrm{O}_{3} \\
\text { (Ni loading of } 8 \% \text { ) }\end{array}$ & $\begin{array}{l}\text { Fixed-bed } \\
\text { reactor }\end{array}$ & Liquid phase & $\begin{array}{c}250{ }^{\circ} \mathrm{C} ; 17.6 \mathrm{MPa} ; \mathrm{WHSV} \\
\text { of } 6.4 \mathrm{~h}^{-1}\end{array}$ & 35 & 62 & [56] \\
\hline $\begin{array}{l}\mathrm{Cu}-\mathrm{Ni} \text { bimetallic } \\
\text { catalyst }\end{array}$ & $\begin{array}{l}\text { Fixed-bed } \\
\text { reactor }\end{array}$ & Liquid phase & $\begin{array}{c}320{ }^{\circ} \mathrm{C} ; 8 \mathrm{MPa} \text {; } \\
\text { ethanol/catalyst ratio of } \\
23.7 ; \mathrm{LHSV}^{-1} \mathrm{~h}^{-1} \\
15 \mathrm{~mL} \mathrm{~g}^{-1} \mathrm{~h}^{-1} \\
18-\mathrm{h} \text { reaction }\end{array}$ & 69.4 & 30.1 & [28] \\
\hline $\begin{array}{c}\mathrm{Cu} / \mathrm{CeO}_{2} \\
(\mathrm{Cu} \text { loading of } 10 \mathrm{wt.} \%)\end{array}$ & $\begin{array}{l}\text { Fixed-bed } \\
\text { reactor }\end{array}$ & Liquid phase & $\begin{array}{c}260{ }^{\circ} \mathrm{C} ; 10 \mathrm{MPa} ; \\
\text { ethanol } / \mathrm{CO}_{2} \text { ratio of } \\
0.05 ; \mathrm{LHSV} \text { of } 1.97 \mathrm{~h}^{-1}\end{array}$ & 67 & 45 & [39] \\
\hline $\begin{array}{l}\mathrm{Cu} / \mathrm{CeO}_{2} \text {-activated } \\
\text { carbon }(\mathrm{Cu} / \mathrm{Ce}=3)\end{array}$ & Batch reactor & Liquid phase & $\begin{array}{c}250{ }^{\circ} \mathrm{C} ; 0.1 \mathrm{MPa} \mathrm{N}_{2} ; \\
\text { ethanol/catalyst ratio of } \\
24.2 ; 48 \text {-h reaction }\end{array}$ & 39.1 & 55.2 & [42] \\
\hline $\begin{array}{c}\mathrm{Ni}-\mathrm{Mg}-\mathrm{AlO} \\
(\mathrm{Ni} / \mathrm{Mg} / \mathrm{Al}=1 / 4 / 1)\end{array}$ & $\begin{array}{l}\text { Fixed-bed } \\
\text { reactor }\end{array}$ & Liquid phase & $\begin{array}{c}250{ }^{\circ} \mathrm{C} ; 3 \mathrm{MPa} ; \mathrm{N}_{2} \text { flow } \\
\text { of } 30 \mathrm{~mL} \mathrm{~min}^{-1} ; \mathrm{WHSV} \\
\text { of } 3.2 \mathrm{~h}^{-1}\end{array}$ & 18.7 & 55.2 & [41] \\
\hline $\begin{array}{c}\mathrm{Pd} / \mathrm{UiO}-66 \\
\text { metal-organic } \\
\text { framework (Pd loading } \\
\text { of } 2 \mathrm{wt} . \%)\end{array}$ & $\begin{array}{l}\text { Fixed-bed } \\
\text { reactor }\end{array}$ & Liquid phase & $\begin{array}{c}250{ }^{\circ} \mathrm{C} ; 2 \mathrm{MPa} ; \\
\mathrm{N}_{2} \text { / ethanol ratio of } 250 ; \\
\mathrm{LHSV} \text { of } 4 \mathrm{~mL} \mathrm{~g}^{-1} \mathrm{~h}^{-1} ; \\
\text { 12-h reaction }\end{array}$ & 49.9 & 50.1 & [44] \\
\hline
\end{tabular}




\section{Butanol Production from Butyric Acid}

Ethanol production via fermentation of organic waste such as sludge, manure, and food waste is much more difficult than typical bioethanol production (i.e., ethanol from corn or sugarcane). The fermentative production of ethanol from organic waste involves the extraction of fermentable sugars from raw food waste through a series of pretreatment and hydrolysis steps. Due to the high moisture content and heterogeneously variable composition of food wastes, these processes are costly, leave behind a significant amount of residual waste, and can produce compounds that may inhibit microorganism activity during fermentation [67]. To avoid these problems, anaerobic digestion is commonly used to treat organic waste. In this process, monomers such as sugars, amino acids, and long-chain fatty acids are produced from complex polymers contained in food waste using hydrolytic bacteria. The monomers are then converted to volatile fatty acids (VFAs) through a series of acidogenesis and acetogenesis steps $[68,69]$. VFAs are carboxylic acids with less than $\mathrm{C}_{6}$ (e.g., acetic acid, propionic acid, butyric acid, isobutyric acid, valeric acid, and isovaleric acid). VFAs are the major intermediate in producing biogas by methanogenesis. Approximately $5.3 \times 10^{5}$ tons of VFA generation in Republic of Korea was estimated [70].

Among different VFAs, butyric acid, which is one of the most dominant in the product produced via anaerobic digestion of organic waste [71-73], has been considered a renewable feedstock for the production of butanol. A conversion route to produce butanol from butyric acid was suggested as a strategy for effective energy recovery from organic waste as a form of liquid fuel [74]. The two-step conversion pathway of butyric acid to butanol is shown in Figure 3 [75]. This pathway involves the production of butyric acid generated by anaerobic digestion of organic waste, which is then upgraded to butanol. The upgrading takes place via two steps: (1) esterification of butyric acid into methyl butyrate and (2) hydrogenolysis of methyl butyrate into butanol.

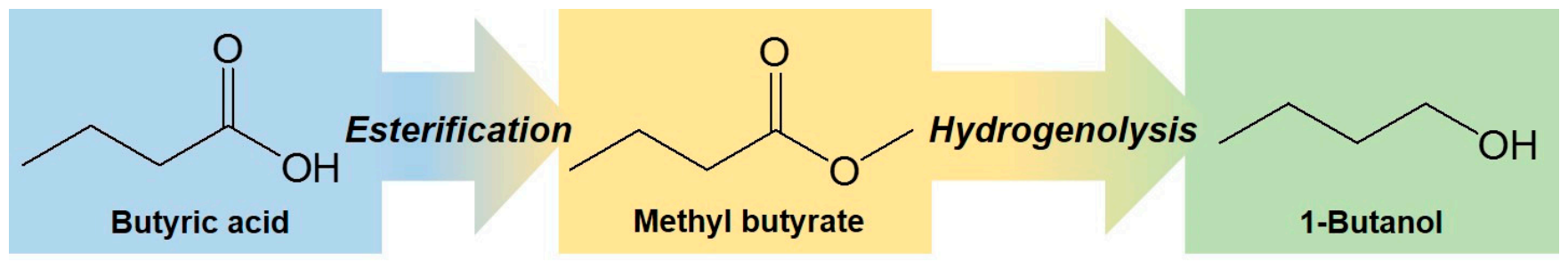

Figure 3. Strategic two-step process for the production of n-butanol from butyric acid. Reprinted from Cho et al. [75], Copyright (2019), with permission from Elsevier.

For the first step of the butyric acid-to-butanol pathway (i.e., esterification of butyric acid to methyl butyrate; Figure 3), researchers have recently demonstrated that porous carbon materials such as carbon nanotubes (CNTs) are an effective catalyst; $\sim 90 \%$ yield was obtained at $360^{\circ} \mathrm{C}$ under $1 \mathrm{~atm}$ (initial pressure) with an butyric acid/methanol volumetric ratio of 0.5 [76]. Table 2 lists other catalytic systems used for the esterification of butyric acid to methyl butyrate.

The esterification of butyric acid to methyl butyrate was found to occur inside the pores of a porous material. To initiate the reaction, the pore size of the porous material needs to be bigger than the kinetic diameter of butyric acid and methanol, which allows the collision between the two reactants [76]. In addition to pore size, pore geometry is also crucial. Hollow-rod-like open pores allow the reactants to readily enter the pores and the product to regularly exit the pores [76]. The surface functionality of the porous material also plays a key role in expediting the esterification reaction, which acts as catalytic sites that activate butyric acid and methanol [77]. 
Table 2. Catalysts used for the esterification of butyric acid to methyl butyrate. All the results are obtained from earlier literature.

\begin{tabular}{cccc}
\hline Catalyst & Reaction Conditions & $\begin{array}{c}\text { Methyl Butyrate } \\
\text { Yield (\%) }\end{array}$ & Ref. \\
\hline $\begin{array}{c}\text { Ordered mesoporous } \\
\text { carbon (CMK-5) }\end{array}$ & $360^{\circ} \mathrm{C}$; VFA / methanol $=0.5(v / v)$ & $\sim 90$ & [76] \\
\hline Carbon black & $370^{\circ} \mathrm{C} ; \mathrm{VFA} /$ methanol $=0.5(v / v)$ & $\sim 75$ & {$[78]$} \\
\hline $\begin{array}{c}\text { Aluminium chloride } \\
\text { hexahydrate } \\
\text { (homogeneous) }\end{array}$ & $\mathrm{VFA} / \mathrm{ethanol}^{\circ} \mathrm{C}$ / motalyst $=1 / 1 / 0.01 ; 8 \mathrm{~h}$ & 26.2 & {$[79]$} \\
\hline $\begin{array}{c}\text { Multi-walled carbon } \\
\text { nanotubes }\end{array}$ & $360^{\circ} \mathrm{C} ; \mathrm{VFA} /$ methanol $=0.5(v / v)$ & 90 & {$[70]$} \\
\hline
\end{tabular}

For the second step of the butyric acid-to-butanol pathway (Figure 3B), a bimetallic $\mathrm{Pt}-\mathrm{Co}$ catalyst was proven to be effective at hydrogenolysis of methyl butyrate to $\mathrm{n}$ butanol [75]. A 54.1\% selectivity toward n-butanol was achieved with a Pt-Co catalyst (Co/Pt molar ratio: 20) at $250{ }^{\circ} \mathrm{C}$ under $5 \mathrm{MPa} \mathrm{H}_{2}$. At above $250{ }^{\circ} \mathrm{C}$ and under above $5 \mathrm{MPa} \mathrm{H}_{2}$, the catalytic activity for the hydrogenolysis of methyl butyrate was deteriorated, leading to a lower selectivity toward n-butanol than that achieved at $250^{\circ} \mathrm{C}$ under $5 \mathrm{MPa}_{2}$. The density-functional theory calculations showed that the activity for the methyl butyrate hydrogenolysis is correlated with the combined adsorption energy of methoxy and butyryl groups. Other catalysts employed for the production of n-butanol via hydrogenolysis are listed in Table 3.

Table 3. Catalysts used for the hydrogenolysis to make n-butanol. All the results are obtained from earlier literature.

\begin{tabular}{|c|c|c|c|c|c|}
\hline Catalyst & Reactor Type & Phase & Reaction Conditions & $\begin{array}{c}\text { Butanol } \\
\text { Yield (\%) }\end{array}$ & Ref. \\
\hline $\begin{array}{c}\mathrm{Co} / \mathrm{SiO}_{2}(\mathrm{Cu} \\
\text { loading of } \\
5 \text { wt. } \%)\end{array}$ & Batch reactor & Liquid phase & $\begin{array}{c}250{ }^{\circ} \mathrm{C} ; 5 \mathrm{MPa} \mathrm{H}_{2} \\
10 \mathrm{~mL} \text { feed } / 0.8 \mathrm{~g} \\
\text { catalyst; } 4 \text {-h reaction }\end{array}$ & 19 & [70] \\
\hline $\begin{array}{l}\mathrm{Pt}-\mathrm{Co} / \mathrm{SiO}_{2} \\
(\mathrm{Co} / \mathrm{Pt} \text { molar } \\
\text { ratio of } 20)\end{array}$ & Batch reactor & Liquid phase & $\begin{array}{c}250{ }^{\circ} \mathrm{C} ; 5 \mathrm{MPa} \mathrm{H}_{2} ; \\
\text { feed/catalyst weight } \\
\text { ratio of } 11.2 ; \\
\text { 12-h reaction }\end{array}$ & 27.6 & [75] \\
\hline $\begin{array}{l}\mathrm{Ru}-\mathrm{Sn} / \mathrm{ZnO} \\
(\mathrm{Sn} / \mathrm{Ru} \text { molar } \\
\text { ratio of } 2)\end{array}$ & $\begin{array}{l}\text { Fixed-bed } \\
\text { reactor }\end{array}$ & Vapor phase & 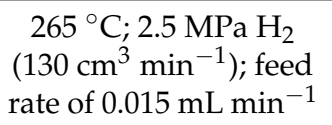 & $>90$ & [80] \\
\hline
\end{tabular}

For the hydrogenolysis of methyl butyrate to n-butanol, methane, methanol, butyl butyrate, and butyric acid were produced as byproducts [70]. Hydrogenolysis of methyl butyrate resulted either in n-butanol and methanol or in butyric acid and methane. Butyl butyrate resulted from transesterification of methyl butyrate and n-butanol. Density functional theory (DFT) calculation showed that the adsorption energy of methoxy and butyryl groups of the reactant molecules on the metal catalyst surface is highly associated with the methyl butyrate hydrogenolysis activity [75].

\section{Butanol Production from Biomass Syngas}

Gasification is a process to make synthesis gas (syngas), primarily composed of $\mathrm{H}_{2}$ and $\mathrm{CO}$, from biomass. Syngas can be used to synthesize ammonia, methanol, and hydrogen. Recently, biomass syngas has been suggested as the feedstock for the production of isobutanol. The isobutanol production mechanism involves three-step consecutive reactions. The first reaction leads to the formation of methanol, the second reaction is to make 
ethanol, and the third reaction is to transform ethanol to isobutanol [81,82]. The addition of formyl intermediate to $\alpha$-carbon in methanol forms ethanol. Aldol condensation of ethanol with methanol makes propanol, and the propanol is reacted with methanol to make isobutanol. It is difficult for isobutanol to undergo aldol condensation due to the lack of two $\beta$-hydrogens needed for its aldol condensation and its steric hindrance; thus, isobutanol is an end product of the chain growth reaction of alcohols. The syngas-to-isobutanol reaction is highly associated with reaction temperature. At low temperatures, linear chain growth taking place via $\mathrm{CO}$ insertion is dominant [83-85]. At high temperatures, however, branched chain growth reaction occurs through aldol-condensation of the linear alcohols produced at low temperatures [82]. Branched alcohols, such as isobutanol, are the primary products. Figure 4 schematically depicts the formation of isobutanol from syngas.

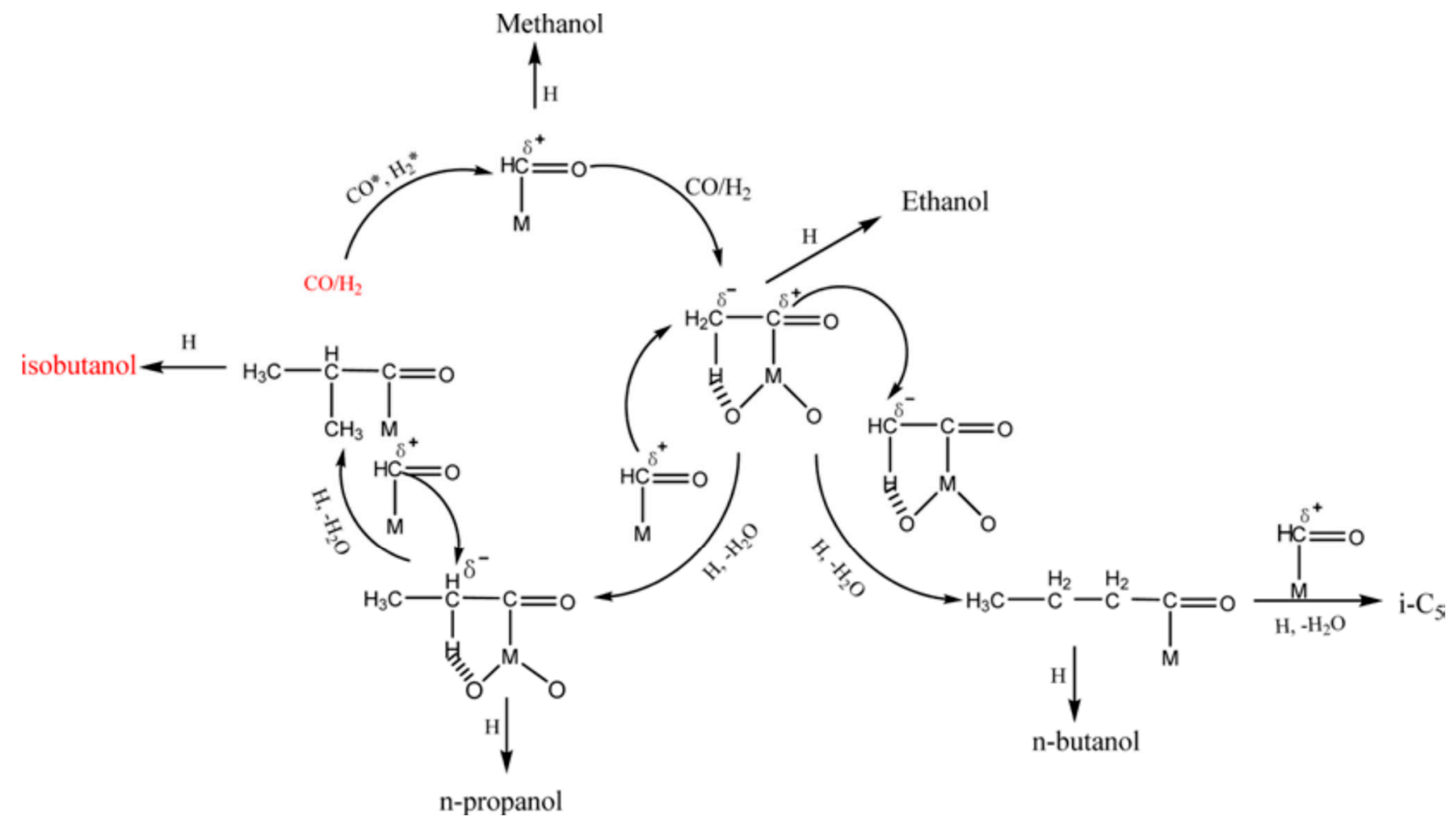

Figure 4. Reaction pathway for the formation of isobutanol from syngas. Reprinted from Wu et al. [82], Copyright (2014), with permission from Elsevier.

Non-precious metal catalysts modified with alkali metal promoter, such as $\mathrm{Zn}-\mathrm{Cr}$ based catalysts modified with $\mathrm{K}$, were reported for the production of isobutanol from syngas owing to high activity and stability [86-88]. The catalysts had high CO conversion (e.g., $10-30 \%$ ) and selectivity toward isobutanol (e.g., $20 \%$ ). This does not necessitate a complex separation process that isolates butanol from the product stream. The effect of various alkali metals modifying the $\mathrm{Cr} / \mathrm{ZnO}$ catalyst on the conversion of syngas to isobutanol was investigated, showing that a $\mathrm{K}$-modified $\mathrm{Cr} / \mathrm{ZnO}$ catalyst had excellent catalytic performance to produce isobutanol from syngas [89]. For the K-modified $\mathrm{Zn}-\mathrm{Cr}$ catalyst, the non-stoichiometric spinel is the active phase for the conversion of syngas to isobutanol [88]. Textual properties, reducibility, and base density of the catalyst are also crucial for the production of isobutanol from biomass syngas.

\section{Economic Approaches for the Catalytic Production of Renewable Butanol}

There are a few studies with an economic assessment of the aforementioned catalytic processes, which deserve to be introduced in this review. Carmona-Garcia et al. compared the economic potential of two biobutanol production processes, such as ABE fermentation and catalytic upgrading of bioethanol [90] (refer Section 2). Given a daily processing scale 
of over 1000 tons, $\mathrm{ABE}$ fermentation provides a higher butanol production (2.59 tons per hour) with a lower net energy consumption $(57.9 \mathrm{GJ}$ per ton of butanol) than the catalytic ethanol upgrading. The minimum selling price of biobutanol was estimated to be 1.56 USD per kg of biobutanol (for ABE fermentation) and 1.80 USD per kg of biobutanol (for catalytic ethanol upgrading).

Kwon and co-workers performed technoeconomic analysis of the two-step butanol production from butyric acid shown in Figure 3 [75] (refer to Section 3). The minimum selling price of n-butanol produced from butyric acid via the two-step process (overall $48 \%$ yield of butanol from butyric acid; energy efficiency of 30\%) was estimated to be 3.4 USD per gallon of gasoline equivalent, which falls within the recent biofuel market prices between 2.0 USD per gallon of gasoline equivalent to 3.8 USD per gallon of gasoline equivalent.

Okoli and Adams developed a model of the catalytic process from lignocellulosic biomass to butanol via syngas [91] (refer Section 4). With the assumption that the crude oil price is over 92 USD per barrel, the minimum selling price of butanol was determined as 0.8 USD per liter of butanol that could compete with the price of petroleum-derived butanol higher than 85.4 USD per barrel of gasoline equivalent. Feedstock costs, coproduct (mixed alcohols) value, and internal rate of return are significant factors that affect the economic viability of the syngas-to-butanol process.

\section{Conclusions}

Butanol from renewable resources such as biomass offers high potential not only for being an alternative to petrol but also being a feedstock for the production of other commodity chemicals. Catalytic routes from biomass-derived compounds to butanol could be classified into (1) ethanol to butanol via chain growth reactions; (2) butyric acid to butanol via esterification and hydrogenolysis; and (3) syngas to butanol via thermochemical consecutive reactions.

Even though the employment of a range of heterogeneous catalysts for the conversion of ethanol to n-butanol has been extensively investigated, evaluation of all available catalytic systems that upgrade ethanol to butanol in terms of economic and environmental points of view is necessary because the technologies are able to aid in high-quality fuel production in an environmentally-friendly way. The evaluation, however, is not easily achieved on a lab scale. Therefore, the studies to evaluate catalyst performance at an industrial scale need to be carefully conducted.

Despite the high performance of the heterogeneous catalytic process to produce butanol from organic waste-derived butyric acid, durability of the catalysts at industrial scales still remains as a challenge. Although many researchers have worked to improve catalyst stability by preventing catalyst deactivation for various reactions [92], they are limited to experimental scales. Further research on improving catalyst lifetime for the ethanol production process from organic waste at large scales must be considered in order to make it more economically viable.

Societal industrial demand for the use of renewable chemicals is important to continuously develop renewable butanol production technologies. The increase in the demand requires financial benefits of capital, operation, and maintenance costs for technologies. To gain the financial benefits, the collection of biomass and organic waste should be a critical part of overall renewable butanol production cycles, and the collection cost is highly associated with legislation [93]. Hence, local systems for feedstock collection and transportation need to be improved to reduce feedstock costs, potentially gaining financial advantages. Application of government legislation further enhances the economics of the technology of renewable butanol production. The development of different process configurations with the intensification of the process would be recommended as future studies.

Author Contributions: Conceptualization, J.L.; writing-original draft preparation, H.C., J.H. and J.L.; writing-review and editing, H.C., J.H. and J.L.; visualization, H.C. and J.H.; supervision, J.L. All authors have read and agreed to the published version of the manuscript. 
Funding: This work was supported by the National Research Foundation of Korea (NRF) grant funded by the Korean Government (Ministry of Science and ICT) (No. NRF-2020R1C1C1003225). This work was also supported by the National Research Foundation of Korea (NRF) grant funded by the Korean government (MSIT) (No. 2021R1A4A1031357).

Institutional Review Board Statement: Not applicable.

Informed Consent Statement: Not applicable.

Data Availability Statement: Not applicable.

Conflicts of Interest: The authors declare no conflict of interest.

\section{References}

1. IndustryARC. Bio-Based Chemicals Market-Global Industry Analysis, Size, Share, Growth, Trends and Forecast 2021-2026. Available online: https:/ / www.industryarc.com/Report/17741/bio-based-chemicals-market.html (accessed on 2 November 2021).

2. Mascal, M. Chemicals from biobutanol: Technologies and markets. Biofuels Bioprod. Bioref. 2012, 6, 483-493. [CrossRef]

3. MarketWatch. N-butanol Market Size, Sale 2021, Regions Will Have the Highest Revenue, Which Will EMERGE in Importance in the Market 2026. Available online: https:/ / www.marketwatch.com/press-release/n-butanol-market-size-sale-2021-regions-willhave-the-highest-revenue-which-will-emerge-in-importance-in-the-market-2026-2021-10-06 (accessed on 8 October 2021).

4. Kushwaha, D.; Srivastava, N.; Mishra, I.; Upadhyay, S.N.; Mishra, P.K. Recent trends in biobutanol production. Rev. Chem. Eng. 2019, 35, 475-504. [CrossRef]

5. Shanmugam, S.; Hari, A.; Kumar, D.; Rajendran, K.; Mathimani, T.; Atabani, A.E.; Brindhadevi, K.; Pugazhendhi, A. Recent developments and strategies in genome engineering and integrated fermentation approaches for biobutanol production from microalgae. Fuel 2021, 285, 119052. [CrossRef]

6. Birgen, C.; Dürre, P.; Preisig, H.A.; Wentzel, A. Butanol production from lignocellulosic biomass: Revisiting fermentation performance indicators with exploratory data analysis. Biotechnol. Biofuels 2019, 12, 167. [CrossRef] [PubMed]

7. Huynh, T.T.; Le, M.D.; Duong, D.N. Effects of butanol-gasoline blends on SI engine performance, fuel consumption, and emission characteristics at partial engine speeds. Int. J. Energy Environ. Eng. 2019, 10, 483-492. [CrossRef]

8. Atmanli, A.; Yilmaz, N. A comparative analysis of n-butanol/diesel and 1-pentanol/diesel blends in a compression ignition engine. Fuel 2018, 234, 161-169. [CrossRef]

9. Capodaglio, A.G.; Bolognesi, S. Ecofuel feedstocks and their prospects. In Advances in Eco-Fuels for a Sustainable Environment; Azad, K., Ed.; Woodhead Publishing: Sawston, Cambridge, UK, 2019; pp. 15-51.

10. Pugazhendhi, A.; Mathimani, T.; Varjani, S.; Rene, E.R.; Kumar, G.; Kim, S.-H.; Ponnusamy, V.K.; Yoon, J.-J. Biobutanol as a promising liquid fuel for the future-Recent updates and perspectives. Fuel 2019, 253, 637-646. [CrossRef]

11. Moon, H.G.; Jang, Y.-S.; Cho, C.; Lee, J.; Binkley, R.; Lee, S.Y. One hundred years of clostridial butanol fermentation. FEMS Microbiol. Lett. 2016, 363, fnw001. [CrossRef]

12. Gu, Y.; Jiang, Y.; Wu, H.; Liu, X.; Li, Z.; Li, J.; Xiao, H.; Shen, Z.; Dong, H.; Yang, Y.; et al. Economical challenges to microbial producers of butanol: Feedstock, butanol ratio and titer. Biotechnol. J. 2011, 6, 1348-1357. [CrossRef] [PubMed]

13. Zheng, Y.-N.; Li, L.-Z.; Xian, M.; Ma, Y.-J.; Yang, J.-M.; Xu, X.; He, D.-Z. Problems with the microbial production of butanol. J. Ind. Microbiol. Biotechnol. 2009, 36, 1127-1138. [CrossRef]

14. Green, E.M. Fermentative production of butanol-The industrial perspective. Curr. Opin. Biotechnol. 2011, 22, 337-343. [CrossRef]

15. Mukhopadhyay, A.; Redding, A.M.; Rutherford, B.J.; Keasling, J.D. Importance of systems biology in engineering microbes for biofuel production. Curr. Opin. Biotechnol. 2008, 19, 228-234. [CrossRef]

16. Ndaba, B.; Chiyanzu, I.; Marx, S. n-Butanol derived from biochemical and chemical routes: A review. Biotechnol. Rep. 2015, 8, 1-9. [CrossRef]

17. Rostrup-Nielsen, J.R. Making fuels from biomass. Science 2005, 308, 1421-1422. [CrossRef] [PubMed]

18. Goldemberg, J. Ethanol for a sustainable energy future. Science 2007, 315, 808-810. [CrossRef]

19. Zhang, M.; Yu, Y. Dehydration of ethanol to ethylene. Ind. Eng. Chem. Res. 2013, 52, 9505-9514. [CrossRef]

20. Angelici, C.; Weckhuysen, B.M.; Bruijnincx, P.C.A. Chemocatalytic conversion of ethanol into butadiene and other bulk chemicals. ChemSusChem 2013, 6, 1595-1614. [CrossRef] [PubMed]

21. Makshina, E.V.; Dusselier, M.; Janssens, W.; Degrève, J.; Jacobs, P.A.; Sels, B.F. Review of old chemistry and new catalytic advances in the on-purpose synthesis of butadiene. Chem. Soc. Rev. 2014, 43, 7917-7953. [CrossRef] [PubMed]

22. Lee, J.; Lee, Y.; Kim, S.; Kwon, E.E.; Lin, K.-Y.A. Catalytic production of hexamethylenediamine from renewable feedstocks. Korean J. Chem. Eng. 2021, 38, 1079-1086. [CrossRef]

23. Statista. Production of Bioethanol Worldwide in 2018, by Region. Available online: https://www.statista.com/statistics/271471 /bioethanol-production-in-selected-countries / (accessed on 11 October 2021).

24. Galadima, A.; Muraza, O. Catalytic upgrading of bioethanol to fuel grade biobutanol: A review. Ind. Eng. Chem. Res. 2015, 54, 7181-7194. [CrossRef]

25. Veibel, S.; Nielsen, J.I. On the mechanism of the Guerbet reaction. Tetrahedron 1967, 23, 1723-1733. [CrossRef] 
26. Santacesaria, E.; Carotenuto, G.; Tesser, R.; Di Serio, M. Ethanol dehydrogenation to ethyl acetate by using copper and copper chromite catalysts. Chem. Eng. J. 2012, 179, 209-220. [CrossRef]

27. Chheda, J.N.; Dumesic, J.A. An overview of dehydration, aldol-condensation and hydrogenation processes for production of liquid alkanes from biomass-derived carbohydrates. Catal. Today 2007, 123, 59-70. [CrossRef]

28. Xi, X.-Y.; Sun, Z.-H.; Cao, H.-T.; Pei, Y.-T.; ten Brink, G.H.; Deuss, P.J.; Barta, K.; Heeres, H.J. Catalyst performance studies on the Guerbet reaction in a continuous flow reactor using mono- and bi-metallic Cu-Ni porous metal oxides. Catalysts 2020, 10, 996. [CrossRef]

29. Wingad, R.L.; Gates, P.J.; Street, S.T.G.; Wass, D.F. Catalytic conversion of ethanol to n-butanol using ruthenium P-N ligand complexes. ACS Catal. 2015, 5, 5822-5826. [CrossRef]

30. Chakraborty, S.; Piszel, P.E.; Hayes, C.E.; Baker, R.T.; Jones, W.D. Highly selective formation of n-butanol from ethanol through the Guerbet process: A tandem catalytic approach. J. Am. Chem. Soc. 2015, 137, 14264-14267. [CrossRef] [PubMed]

31. Tseng, K.-N.T.; Lin, S.; Kampf, J.W.; Szymczak, N.K. Upgrading ethanol to 1-butanol with a homogeneous air-stable ruthenium catalyst. Chem. Commun. 2016, 52, 2901-2904. [CrossRef]

32. Xie, Y.; Ben-David, Y.; Shimon, L.J.W.; Milstein, D. Highly efficient process for production of biofuel from ethanol catalyzed by ruthenium pincer complexes. J. Am. Chem. Soc. 2016, 138, 9077-9080. [CrossRef]

33. Aitchison, H.; Wingad, R.L.; Wass, D.F. Homogeneous ethanol to butanol catalysis-Guerbet renewed. ACS Catal. 2016, 6, 7125-7132. [CrossRef]

34. Fu, S.; Shao, Z.; Wang, Y.; Liu, Q. Manganese-catalyzed upgrading of ethanol into 1-butanol. J. Am. Chem. Soc. 2017, 139, 11941-11948. [CrossRef]

35. Kulkarni, N.V.; Brennessel, W.W.; Jones, W.D. Catalytic upgrading of ethanol to n-butanol via manganese-mediated Guerbet reaction. ACS Catal. 2018, 8, 997-1002. [CrossRef]

36. Neumann, C.N.; Rozeveld, S.J.; Yu, M.; Rieth, A.J.; Dincă, M. Metal-organic framework-derived Guerbet catalyst effectively differentiates between ethanol and butanol. J. Am. Chem. Soc. 2019, 141, 17477-17481. [CrossRef] [PubMed]

37. Cole-Hamilton, D.J. Homogeneous catalysis-new approaches to catalyst separation, recovery, and recycling. Science 2003, 299, 1702-1706. [CrossRef]

38. Dev, A.; Srivastava, A.K.; Karmakar, S. New generation hybrid nanobiocatalysts: The catalysis redefined. In Handbook of Nanomaterials for Industrial Applications; Mustansar Hussain, C., Ed.; Elsevier: Amsterdam, The Netherlands, 2018 ; pp. 217-231. [CrossRef]

39. Earley, J.H.; Bourne, R.A.; Watson, M.J.; Poliakoff, M. Continuous catalytic upgrading of ethanol to n-butanol and $>\mathrm{C}_{4}$ products over $\mathrm{Cu} / \mathrm{CeO}_{2}$ catalysts in supercritical $\mathrm{CO}_{2}$. Green Chem. 2015, 17, 3018-3025. [CrossRef]

40. Ho, C.R.; Shylesh, S.; Bell, A.T. Mechanism and kinetics of ethanol coupling to butanol over hydroxyapatite. ACS Catal. 2016, 6, 939-948. [CrossRef]

41. Pang, J.; Zheng, M.; He, L.; Li, L.; Pan, X.; Wang, A.; Wang, X.; Zhang, T. Upgrading ethanol to n-butanol over highly dispersed $\mathrm{Ni}-\mathrm{MgAlO}$ catalysts. J. Catal. 2016, 344, 184-193. [CrossRef]

42. Jiang, D.; Wu, X.; Mao, J.; Ni, J.; Li, X. Continuous catalytic upgrading of ethanol to n-butanol over $\mathrm{Cu}_{-\mathrm{CeO}} / \mathrm{AC}$ catalysts. Chem. Commun. 2016, 52, 13749-13752. [CrossRef]

43. Wu, X.; Fang, G.; Liang, Z.; Leng, W.; Xu, K.; Jiang, D.; Ni, J.; Li, X. Catalytic upgrading of ethanol to n-butanol over M-CeO 2 / AC $(\mathrm{M}=\mathrm{Cu}, \mathrm{Fe}, \mathrm{Co}, \mathrm{Ni}$ and $\mathrm{Pd})$ catalysts. Catal. Commun. 2017, 100, 15-18. [CrossRef]

44. Jiang, D.; Fang, G.; Tong, Y.; Wu, X.; Wang, Y.; Hong, D.; Leng, W.; Liang, Z.; Tu, P.; Liu, L.; et al. Multifunctional Pd@UiO-66 catalysts for continuous catalytic upgrading of ethanol to n-butanol. ACS Catal. 2018, 8, 11973-11978. [CrossRef]

45. Scalbert, J.; Thibault-Starzyk, F.; Jacquot, R.; Morvan, D.; Meunier, F. Ethanol condensation to butanol at high temperatures over a basic heterogeneous catalyst: How relevant is acetaldehyde self-aldolization? J. Catal. 2014, 311, 28-32. [CrossRef]

46. Kozlowski, J.T.; Davis, R.J. Sodium modification of zirconia catalysts for ethanol coupling to 1-butanol. J. Energy Chem. 2013, 22, 58-64. [CrossRef]

47. Ogo, S.; Onda, A.; Yanagisawa, K. Selective synthesis of 1-butanol from ethanol over strontium phosphate hydroxyapatite catalysts. Appl. Catal. A Gen. 2011, 402, 188-195. [CrossRef]

48. Ogo, S.; Onda, A.; Iwasa, Y.; Hara, K.; Fukuoka, A.; Yanagisawa, K. 1-Butanol synthesis from ethanol over strontium phosphate hydroxyapatite catalysts with various $\mathrm{Sr} / \mathrm{P}$ ratios. J. Catal. 2012, 296, 24-30. [CrossRef]

49. Ndou, A.S.; Plint, N.; Coville, N.J. Dimerisation of ethanol to butanol over solid-base catalysts. Appl. Catal. A Gen. 2003, 251, 337-345. [CrossRef]

50. Yang, C.; Meng, Z.Y. Bimolecular condensation of ethanol to 1-butanol catalyzed by alkali cation zeolites. J. Catal. 1993, 142, 37-44. [CrossRef]

51. Carvalho, D.L.; de Avillez, R.R.; Rodrigues, M.T.; Borges, L.E.P.; Appel, L.G. Mg and Al mixed oxides and the synthesis of n-butanol from ethanol. Appl. Catal. A Gen. 2012, 415-416, 96-100. [CrossRef]

52. Carvalho, D.L.; Borges, L.E.P.; Appel, L.G.; Ramírez de la Piscina, P.; Homs, N. In situ infrared spectroscopic study of the reaction pathway of the direct synthesis of n-butanol from ethanol over MgAl mixed-oxide catalysts. Catal. Today 2013, 213, 115-121. [CrossRef]

53. León, M.; Díaz, E.; Ordóñez, S. Ethanol catalytic condensation over Mg-Al mixed oxides derived from hydrotalcites. Catal. Today 2011, 164, 436-442. [CrossRef] 
54. Marcu, I.-C.; Tichit, D.; Fajula, F.; Tanchoux, N. Catalytic valorization of bioethanol over Cu-Mg-Al mixed oxide catalysts. Catal. Today 2009, 147, 231-238. [CrossRef]

55. Riittonen, T.; Toukoniitty, E.; Madnani, D.K.; Leino, A.-R.; Kordas, K.; Szabo, M.; Sapi, A.; Arve, K.; Wärnå, J.; Mikkola, J.-P. One-pot liquid-phase catalytic conversion of ethanol to 1-butanol over aluminium oxide-the effect of the active metal on the selectivity. Catalysts 2012, 2, 68-84. [CrossRef]

56. Ghaziaskar, H.S.; Xu, C. One-step continuous process for the production of 1-butanol and 1-hexanol by catalytic conversion of bio-ethanol at its sub-/supercritical state. RSC Adv. 2013, 3, 4271-4280. [CrossRef]

57. Dowson, G.R.M.; Haddow, M.F.; Lee, J.; Wingad, R.L.; Wass, D.F. Catalytic conversion of ethanol into an advanced biofuel: Unprecedented selectivity for n-butanol. Angew. Chem. Int. Ed. 2013, 52, 9005-9008. [CrossRef]

58. Riittonen, T.; Eränen, K.; Mäki-Arvela, P.; Shchukarev, A.; Rautio, A.-R.; Kordas, K.; Kumar, N.; Salmi, T.; Mikkola, J.-P. Continuous liquid-phase valorization of bio-ethanol towards bio-butanol over metal modified alumina. Renew. Energy 2015, 74, 369-378. [CrossRef]

59. Sadjadi, M.; Ebadi, A.; Zare, K. Oxidation of alcohols with tert-butylhydroperoxide catalyzed by nano-sized $\gamma$-alumina supported metallophthalocyanines. React. Kinet. Mech. Catal. 2010, 99, 119-124. [CrossRef]

60. Ji, X.; Chen, Y.; Wang, X.; Liu, W. Preparation of nano- $\mathrm{SO}_{4}{ }^{2-} / \mathrm{TiO}_{2}$ catalyst and its application in esterification of sebacic acid with 2-ethyl hexanol. Kinet. Catal. 2011, 52, 222-225. [CrossRef]

61. Ji, X.B.; Chen, Y.X.; Shen, Z.; Chen, Y.X. Nano-SO ${ }_{4}{ }^{2-} / \mathrm{TiO}_{2}$ catalyzed eco-friendly esterification of dicarboxylic acids. Asian J. Chem. 2014, 26, 5769-5772. [CrossRef]

62. Abd El-Hafiz, D.R.; Ebiad, M.A.; Elsalamony, R.A.; Mohamed, L.S. Highly stable nano Ce-La catalyst for hydrogen production from bio-ethanol. RSC Adv. 2015, 5, 4292-4303. [CrossRef]

63. Sun, K.-Q.; Luo, S.-W.; Xu, N.; Xu, B.-Q. Gold nano-size effect in $\mathrm{Au} / \mathrm{SiO}_{2}$ for selective ethanol oxidation in aqueous solution. Catal. Lett. 2008, 124, 238-242. [CrossRef]

64. Viswanadham, N.; Saxena, S.K.; Kumar, J.; Sreenivasulu, P.; Nandan, D. Catalytic performance of nano crystalline H-ZSM-5 in ethanol to gasoline (ETG) reaction. Fuel 2012, 95, 298-304. [CrossRef]

65. Tsuchida, T.; Sakuma, S.; Takeguchi, T.; Ueda, W. Direct synthesis of n-butanol from ethanol over nonstoichiometric hydroxyapatite. Ind. Eng. Chem. Res. 2006, 45, 8634-8642. [CrossRef]

66. Marcu, I.-C.; Tanchoux, N.; Fajula, F.; Tichit, D. Catalytic conversion of ethanol into butanol over M-Mg-Al mixed oxide catalysts $(\mathrm{M}=\mathrm{Pd}, \mathrm{Ag}, \mathrm{Mn}, \mathrm{Fe}, \mathrm{Cu}, \mathrm{Sm}, \mathrm{Yb})$ obtained from LDH precursors. Catal. Lett. 2013, 143, 23-30. [CrossRef]

67. Matsakas, L.; Kekos, D.; Loizidou, M.; Christakopoulos, P. Utilization of household food waste for the production of ethanol at high dry material content. Biotechnol. Biofuels 2014, 7, 4. [CrossRef]

68. Sans, C.; Mata-Alvarez, J.; Cecchi, F.; Pavan, P.; Bassetti, A. Acidogenic fermentation of organic urban wastes in a plug-flow reactor under thermophilic conditions. Bioresour. Technol. 1995, 54, 105-110. [CrossRef]

69. Cavinato, C.; Da Ros, C.; Pavan, P.; Bolzonella, D. Influence of temperature and hydraulic retention on the production of volatile fatty acids during anaerobic fermentation of cow manure and maize silage. Bioresour. Technol. 2017, 223, 59-64. [CrossRef] [PubMed]

70. Cho, S.-H.; Kim, T.; Baek, K.; Lee, J.; Kwon, E.E. The use of organic waste-derived volatile fatty acids as raw materials of $\mathrm{C}_{4}$ - $\mathrm{C}_{5}$ bioalcohols. J. Clean. Prod. 2018, 201, 14-21. [CrossRef]

71. Wang, K.; Yin, J.; Shen, D.; Li, N. Anaerobic digestion of food waste for volatile fatty acids (VFAs) production with different types of inoculum: Effect of pH. Bioresour. Technol. 2014, 161, 395-401. [CrossRef] [PubMed]

72. Banks, C.J.; Chesshire, M.; Heaven, S.; Arnold, R. Anaerobic digestion of source-segregated domestic food waste: Performance assessment by mass and energy balance. Bioresour. Technol. 2011, 102, 612-620. [CrossRef] [PubMed]

73. Liotta, F.; d'Antonio, G.; Esposito, G.; Fabbricino, M.; van Hullebusch, E.D.; Lens, P.N.; Pirozzi, F.; Pontoni, L. Effect of total solids content on methane and volatile fatty acid production in anaerobic digestion of food waste. Waste Manag. Res. 2014, 32, 947-953. [CrossRef]

74. Jung, J.-M.; Cho, J.; Kim, K.-H.; Kwon, E.E. Pseudo catalytic transformation of volatile fatty acids into fatty acid methyl esters. Bioresour. Technol. 2016, 203, 26-31. [CrossRef] [PubMed]

75. Cho, S.-H.; Kim, J.; Han, J.; Lee, D.; Kim, H.J.; Kim, Y.T.; Cheng, X.; Xu, Y.; Lee, J.; Kwon, E.E. Bioalcohol production from acidogenic products via a two-step process: A case study of butyric acid to butanol. Appl. Energy 2019, 252, 113482. [CrossRef]

76. Lee, J.; Jung, J.-M.; Kim, H.J.; Kim, T.-W.; Kim, K.-H.; Kwon, E.E. Methylation of volatile fatty acids with ordered mesoporous carbon and carbon nanotube for renewable energy application. ACS Sustain. Chem. Eng. 2017, 5, 7433-7438. [CrossRef]

77. Lee, A.F.; Bennett, J.A.; Manayil, J.C.; Wilson, K. Heterogeneous catalysis for sustainable biodiesel production via esterification and transesterification. Chem. Soc. Rev. 2014, 43, 7887-7916. [CrossRef]

78. Kwon, E.E.; Jung, J.-M.; Kim, H.J.; Lee, J. Sustainable production of alkyl esters via thermal process in the presence of carbon black. Environ. Res. 2020, 183, 109199. [CrossRef] [PubMed]

79. di Bitonto, L.; Menegatti, S.; Pastore, C. Process intensification for the production of the ethyl esters of volatile fatty acids using aluminium chloride hexahydrate as a catalyst. J. Clean. Prod. 2019, 239, 118122. [CrossRef]

80. Lee, J.-M.; Upare, P.P.; Chang, J.-S.; Hwang, Y.K.; Lee, J.H.; Hwang, D.W.; Hong, D.-Y.; Lee, S.H.; Jeong, M.-G.; Kim, Y.D.; et al. Direct hydrogenation of biomass-derived butyric acid to n-butanol over a ruthenium-tin bimetallic catalyst. ChemSusChem 2014, 7, 2998-3001. [CrossRef] [PubMed] 
81. Wu, Y.; Xie, H.; Tian, S.; Tsubaki, N.; Han, Y.; Tan, Y. Isobutanol synthesis from syngas over $\mathrm{K}-\mathrm{Cu} / \mathrm{ZrO}_{2}-\mathrm{La}_{2} \mathrm{O}_{3}(x)$ catalysts: $\mathrm{Effect}$ of La-loading. J. Mol. Catal. A Chem. 2015, 396, 254-260. [CrossRef]

82. Wu, Y.; Xie, H.; Kou, Y.; Tsubaki, N.; Han, Y.; Tan, Y. The mechanism of higher alcohol formation on $\mathrm{ZrO}_{2}$-based catalyst from syngas. Korean J. Chem. Eng. 2015, 32, 406-412. [CrossRef]

83. Hilmen, A.-M.; Xu, M.; Gines, M.J.L.; Iglesia, E. Synthesis of higher alcohols on copper catalysts supported on alkali-promoted basic oxides. Appl. Catal. A Gen. 1998, 169, 355-372. [CrossRef]

84. Fang, K.; Li, D.; Lin, M.; Xiang, M.; Wei, W.; Sun, Y. A short review of heterogeneous catalytic process for mixed alcohols synthesis via syngas. Catal. Today 2009, 147, 133-138. [CrossRef]

85. Dorokhov, V.S.; Ishutenko, D.I.; Nikul'shin, P.A.; Eliseev, O.L.; Rozhdestvenskaya, N.N.; Kogan, V.M.; Lapidus, A.L. The mechanism of synthesis gas conversion to alcohols catalyzed by transition metal sulfides. Dokl. Chem. 2013, 451, 191-195. [CrossRef]

86. Keim, W.; Falter, W. Isobutanol from synthesis gas. Catal. Lett. 1989, 3, 59-63. [CrossRef]

87. Forzatti, P.; Tronconi, E.; Pasquon, I. Higher alcohol synthesis. Catal. Rev. Sci. Eng. 1991, 33, 109-168. [CrossRef]

88. Tian, S.; Ding, S.; Yang, Q.; Ren, H.; Ma, Q.; Zhao, Y.; Miao, Z. The role of non-stoichiometric spinel for iso-butanol formation from biomass syngas over Zn-Cr based catalysts. RSC Adv. 2017, 7, 20135-20145. [CrossRef]

89. Tan, L.; Yang, G.; Yoneyama, Y.; Kou, Y.; Tan, Y.; Vitidsant, T.; Tsubaki, N. Iso-butanol direct synthesis from syngas over the alkali metals modified $\mathrm{Cr} / \mathrm{ZnO}$ catalysts. Appl. Catal. A Gen. 2015, 505, 141-149. [CrossRef]

90. Carmona-Garcia, E.; Marín-Valencia, P.A.; Solarte-Toro, J.C.; Moustakas, K.; Cardona-Alzate, C.A. Comparison of acetonebutanol-ethanol fermentation and ethanol catalytic upgrading as pathways for butanol production: A techno-economic and environmental assessment. Biofuel Res. J. 2021, 8, 1384-1399. [CrossRef]

91. Okoli, C.; Adams, T.A. Design and economic analysis of a thermochemical lignocellulosic biomass-to-butanol process. Ind. Eng. Chem. Res. 2014, 53, 11427-11441. [CrossRef]

92. Kim, S.; Tsang, Y.F.; Kwon, E.E.; Lin, K.-Y.A.; Lee, J. Recently developed methods to enhance stability of heterogeneous catalysts for conversion of biomass-derived feedstocks. Korean J. Chem. Eng. 2019, 36, 1-11. [CrossRef]

93. Tchobanoglous, G.; Theisen, H.; Vigil, S.A. Integrated Solid Waste Management: Engineering Principles and Management Issues; McGraw-Hill, Inc.: Hightstown, NJ, USA, 1993. 